\title{
砂地盘の海底における筒状体の地切り力に対する 周面摩擦力の影響に関する実験的研究 \\ EXPERIMENTAL STUDY ON SKIN FRICTIONAL FORCE OF CYLINDRICAL OBJECTS PULLED OUT FROM SAND SEA-FLOOR
}

\author{
井上令 作*・岩 井 勝 美** \\ By Reisaku INOUE and Masami IWAI
}

\section{1. まえがき}

海底から物体や基礎などを引き抜く場合, その引き抜 き抵抗力, すなわち, 地切り力の大きさを推定すること は非常に重要なことである.作業船が海中工事や海中作 業に従事し, 海底から物体や基礎などを引き上げると き，その地切り力を前もって算定しておくことは，作業 船の作業能率の上からも必要なことである.また, 海洋 開発に使用される着底式石油掘削台船や作業台船では, 脚やマットに作用する地切り力が大きい場合には, 脚や マットの引き上げが困難となることから，これらに作用 する地切り力を推定すること，およびその地切り力を減 少させることが課題となっている.

現在, 海底に着地している物体や基礎の地切りカに関 する研究は，そのほとんどが粘性地盤に関するものであ

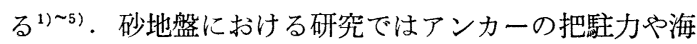
底埋没体の引き上げ抵抗力の研究として見らけられるも のはあるが(6) そ)，それらはいずれも陸上における研究の 延長であり，吸引力などについてくわしく考察している ものはない，また，海洋作業台船の脚の地切り力に関す る研究は少なく”，これも粘性地盤に関するものである. 一方, わが国に拉ける着底式海洋作業台船の脚の地切り 力については, 現在, 基礎的な研究と並行して, 実際に 稼動している台船でのデータの収集を行っている段階で あり，まだ，簡単な目安としての值しか提出されていな い9).これらはいずれ解決していかなければならない重 要な問題である.

筆者らは, 砂地盤の海底に着地している物体や基礎な どを引き抜く場合の地切りカについて, 筒状模型を用い た実験をもとに研究を行ってきた. 一般に, 筒状体の地 切り力はその底面に作用する吸引力 (Suction Force) と

\footnotetext{
* 正会宣，運輸省船舶技術研究所 海洋開発工学部
}

** 湦輸省船舶技術研究所 海洋開発工学部
周面に作用する摩擦力の和として表わすことができる. しかし, 海底に着地しているような物体や基礎は杭など と異なり，大きさに比較して根入り深さが 小さいため に，地切り力のうちで吸引力のしめる割合が大きく，地 切り力を求める場合には, 吸引力の算定が重要である.

前報 ${ }^{10)}$ では, 砂地盤の海底から筒状体を引き抜く場合, その底面に作用する吸引力について考察を行った．その 結果, 吸引力の発生現象を透水現象と対応させることに より, 浸透流の理論を基礎とし, 筒状模型を用いた実験 結果をもとに吸引力の算定式を誘導することができた．

本論文では前報に引き続き, 地切りカのもう一方の要 素である周面摩擦力と, 地切り力について述べたもので ある. 海底に着地している物体や基礎は根入り深さが小 さいために, 周面摩擦力は底面に発生する吸引力の影響 をらける.すなわち, 吸引力の発生にともない周面の水 圧が減少し, 有効応力が増加するために周面摩擦力は吸 引力の関数として表わされ，杭などに用いられる静力学 的な周面摩擦力だけでは解決できない，そのために，実 験では模型の底面の水圧を計測すると同時に周面に作用 する水圧も計測し，吸引力の発生により増加する周面摩 擦力についてくわしく考察した。

以上のように, 吸引力および周面摩擦力を考察するこ とにより, 砂地盤の海底に着地している筒状物体や基礎 の地切り力の算定式を求めることができた.

\section{2. 周面水圧の計測}

周面摩擦力を考察するために, 吸引力の発生により減 少する筒状体周面の水圧を計測した. しかし, 周面摩擦 力や地切りカのデータとしては前報 ${ }^{10)}$ で行った実験結果 がそのまま使用できるので, その実験装置の簡単な概要 と周面水圧の計測方法について述べる.

まず, 実験装置は幅 $100 \mathrm{~cm}$, 高さ $75 \mathrm{~cm}$, 奥行 $68 \mathrm{~cm}$ の水砂槽と模型を引き上げるための駆動装置である. 使 
用した筒状模型は円筒模型 2 種類 (CIRCULAR (1): 㨁径 $2 B=10 \mathrm{~cm}$, 底面積 $A=78.54 \mathrm{~cm}^{2}$, 周長 $L=31.42$ $\mathrm{cm}$, CIRCULAR (2) : $2 B=15 \mathrm{~cm}, A=176.71 \mathrm{~cm}^{2}$, $L=47.12 \mathrm{~cm}$ ) および円筒模型（1）と同一底面積を有す る正三角筒模型と正四角筒模型の計 4 種類である. 実験 砂は豊浦標準砂 (SAND I : 乾燥密度 $r_{d}=1.60 \mathrm{~g} / \mathrm{cm}^{3}$, 閒隙比 $e=0.64$, 透水係数 $k_{20}{ }^{\circ} \mathrm{C}=0.017 \mathrm{~cm} / \mathrm{sec}$ ） と鬼怒 川砂 (SAND II : $\gamma_{d}=1.54 \mathrm{~g} / \mathrm{cm}^{3}, e=0.77, \quad k_{20^{\circ} \mathrm{C}}=$ $0.025 \mathrm{~cm} / \mathrm{sec}$ ) の 2 種類を用いた. 計測装置としては, 模型の引き上げ力を計測するための張力計と模型の鉛直 方向の移動量を計測するための变位計, および吸引力を 計測するために模型の底面に取り付けた 3 個の水圧計で ある.これらは前報 ${ }^{10)} て ゙$ 述べたが, 本論文の主題である 周面摩擦力を考察するために, 模型の底面の水圧と同時 に周面水圧も計測する実験を追加した.

この周面水厓計測のための実験 は SAND I の砂 で, CIRCULAR (2) の模型を用いて行った. 水圧計 の取り付け位置は Fig. 1 に示すように底面に 3 個, 周 面に 3 個の計 6 個である. 水圧計の先端には取り付け金 具をつけ, 水圧計の受圧板が直接砂粒子に接触しないよ うにしてある. しかし, 周面では砂粒子と模型がすれ合 うために，取り付け金具の先端にある水圧取りだし孔

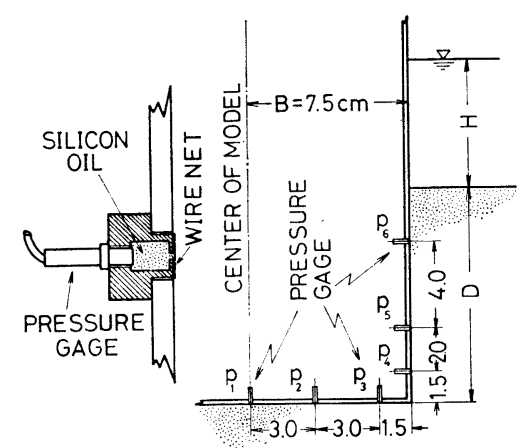

Fig. 1 Arrangement of Pressure Gage

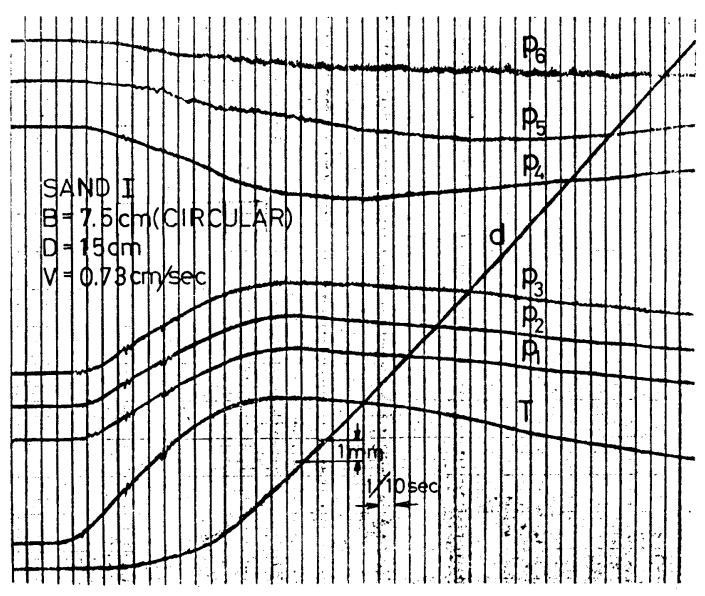

Fig. 2 Record of Pulling Test
（直径 $1 \mathrm{~mm}$ ）に入った砂粒子が，才机合いにより微動 し, 水圧計の記録が乱れる. そのために，周再の水圧計 については, Fig. 1 に示すように, 水圧取りだし孔の 前面に 網目の非常に小さい金網を取り付けることによ り, Fig. 2 に示すように, きれいな記録 $\left(p_{4}, p_{5}, p_{6}\right)$ をとることができた.

Fig. 2 は実験の記録の一例である. $d$ は模型の鉛直 変位, $T$ は引き上げ力 (地切り力) $, p_{1}, p_{2}, p_{3}$ は底面 に作用する水圧 (吸引力) $, p_{4}, p_{5}, p_{6}$ は周面に作用す る水圧の記録である. ここで, 周面水圧 $p_{4}, p_{5}, p_{6}$ の 記録と底面水圧 $p_{1}, p_{2}, p_{3}$ の記録の方向が逆になってい るが、これは記録を読み取りやすいように，両者の記録 方向を逆にしたものであり, 実際の現象では両者とも減 圧として作用している．また,この記録でわかるように， 地切り力, 吸引力, 周面水圧はいずれも極大值を有し, その極大值の位相はそれぞれ異なっている.この中で, 底面に取り付けた 3 個の水圧計の記録は，いずれも極大 值の位相は同じで，また，その大きさや形状も同じであ ることから, 底面における吸引力の分布は等分布である ことが推測できる ${ }^{10)}$. しかし，ここでは最小根入れ深さ $D=5 \mathrm{~cm}$, すなわち, 根入れ幅比 $D / 2 B=0.33$ までし か実験を行っていない.この範囲では, 吸引力の分布は 等分布となることが実験で確認できたが， $D / 2 B$ が上記 の值よりも小さくなってくるにしたがって，おそらく吸 引力の分布は順次底面中央に凸型の形状になっていくも

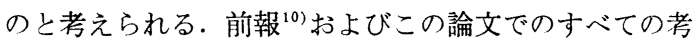
察は, 吸引力の分布は等分布であることを前提としてい るためにこの論文でとりあつから範囲は $D / 2 B$ が約 0.3 よりも大きい範囲に限られる. したがって, 根入り 深さが非常に小さくなり, 吸引力が等分布に発生しなく なる場合については, 今後, 研究を行い考察していきた いと考えている.

一方, 周面水圧の極大值の位置は吸引力の極大值の位 置と大分ずれていて，水圧計の取り付け位置が上方にな るほど位相のずれは大きく， $p_{6}$ では極大値が現われて いない.

\section{3. 筒状体の周面摩擦力}

一般に砂地盤の海底から筒状体を引き上げるときの地 切り力は次のよらな式で表わすことができる.

$$
T=P+F+(W-U)
$$

ここで, $T$ は地切り力, $P$ は底洎に作用する吸引力 の合力， $F$ は周面の摩擦力， $W, U$ はそれぞれ筒状体 の自重と浮力である. 地切り力 $T$ は $P$ および $F$ をそ れぞれ考察することにより求めることができる．前報 ${ }^{10)}$ では吸引力 $P$ について考察したが，本報での目的は周 
面摩擦力 $F$ を考察し, 筒状体の地切り力の算定式を求 めることである.

Fig. 3 は Fig. 2 の記録を読みとり，模型を引き上 げたとき模型に作用する力の変化を鉛直変位 $d$ に応じて 表わしたものである．P は模型底面に作用する吸引力の 合力であり, 底面で計測した単位面積あたりの吸引力 $p_{1}, p_{2}, p_{3}$ の平均值 $p$ に底面積 $A$ を乗じた值である. $F$ は模型の周面に作用する摩擦力であるが, 実験では直 接計測できないので, $F=T-P-(W-U)$ で計算し破 線で記入してある. $W-U$ は模型の重量と浮力の差で あり浮力の変化を示している.この図でわかるように, 鉛直変位 $d$ に対する $T, P, F$ の変化は, いずれも最初 急激に増加し, 極大值に達したのち, ゆるやかに減少し ている.これらの極大值の発生点はそれぞれ少しずつず れているが,この発生順位はすべての実験において Fig. 3 と同様に $F, T, P$ の順序であった. また, 地切り力 $T$ が極大值 $T_{p}$ に達するまでの鉛直変位は, 底面積 $A$ と引き上げ速度 $V$ との積 $A V$ の值が大なるほど大き く, 行ったすべての実験では $0.1 \sim 1.0 \mathrm{~cm}$ の間で極大值 は発生している.これらの極大值にはその記号の Suffix にp をつけて表わした. しかし, われわれが地切り力 として必要とする值は $T$ の極大值 $T_{p}$ であり, $T_{p}$ を 算定するのに必要な值は $T_{p}$ が発生した瞬間における $P, F, W-U$ の值, すなわち, $P_{t}, F_{t}, W-U_{t}$ の值で ある.このように地切り力の極大值 $T_{p}$ に対応する值 にはすべてその記号の Suffix に $t$ をつけてある.

前報 ${ }^{10)}$ では, この吸引力 $P$ について考察し, 吸引力

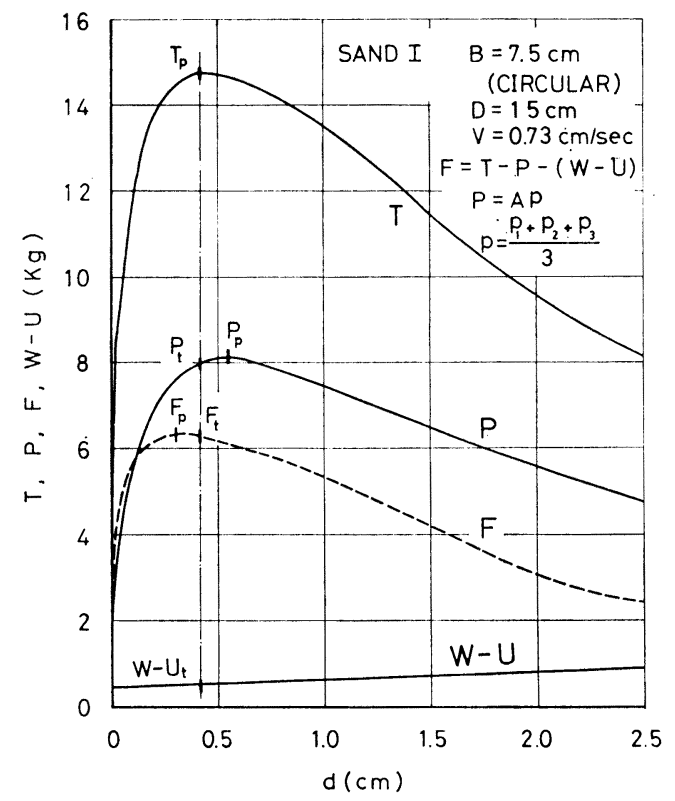

Fig. 3 Variations of Pulling Force, Suction Force, Frictional Force and Buoyancy to Displacement of Model
の発生現象を透水現象と対応させて, その計算式を導く ことができた. すなわち, 単位面積あたりの吸引力 $p_{p}$ と $p_{t}$ は次式で計算できる.

$$
\begin{aligned}
& p_{p}=1.279\left(\frac{\Phi_{r_{w}} A V}{\alpha k L}\right)^{0.713} \\
& p_{t}=1.188\left(\frac{\Phi_{r_{w}} A V}{\alpha k L}\right)^{0.726}
\end{aligned}
$$

これらの式で, $A$ および $L$ は筒状体の底面積と周 長, $V$ は筒状体の引き上げ速度, $k$ は透水係数, $r_{w}$ は 水の単位体積重量, $1 / \Phi$ は形状係数, $\alpha$ は 2 次元流量を 3 次元流量になおすための補正係数である. なお, これ らの式を使用する場合には $\mathrm{cm}, \mathrm{g}, \mathrm{sec}$ の単位を用いな ければならない。

この章では周面摩擦力, 特に, 吸引力の発生によって 増加する周面摩擦力について考察する. そのためには, まず周面に作用する水圧の分布形状を調べ, 次に, 周面 摩擦力に対する吸引力の影響について考察し, 最後に周 面摩擦力の算定式を求める.

\section{（1）吸引力の発生により減少する周面水圧の 分布形状}

筒状体の周面摩擦力を考察するにあたっては, 周面に 作用する水圧の変化を把握しておくことが重要である. 筒状体を引き上げるとその底面に吸引力が発生し, それ に応じて周面の水圧も減少する. Fig. 4 は Fig. 2 の 記録を読みとり, 吸引力 $p$ 扩よび周面に作用する水圧 $p_{4}, p_{5}, p_{6}$ の変化を模型の鉛直変位 $d$ に応じて示した ものである. $p$ は底面の 3 筒所で計測した $p_{1}, p_{2}, p_{3}$ の 平均值である. この図でわかるように, 周面水圧も吸引 力と同様に極大值を有している. その極大值は吸引力の 極大值の発生点からかなりおくれて発生し, 深さが小さ

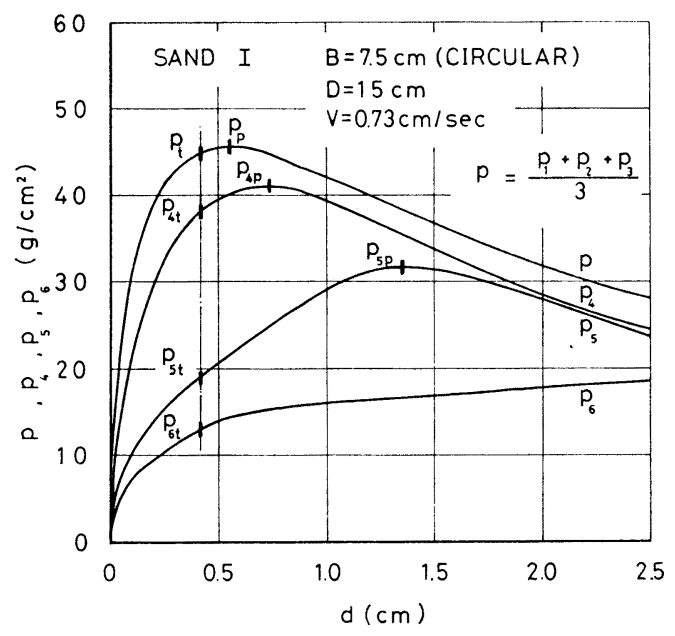

Fig. 4 Variations of Suction Pressure and Decreased Side Water Pressure to Displacement of Model 
いほどそのおくれが大きい，しかし，われわれが必要と する值は， Fig. 3 のところでも述べたように，地切り 力の極大值が 発生した瞬間における水圧 $\left(p_{t}, p_{4 t}, p_{5 t}\right.$, $\left.p_{6 t}\right)$ の值であり, 今後の解析に㧍いては, すべてこの水 圧を対象とする.

Fig. 5 は模型を引き上げたとき，その底面に発生す る吸引力 $p_{t}$ と周面に作用寸る水圧 $p_{4 t}, p_{5 t}, p_{6 t}$ の実 測值の分布を示したものである. 底面の吸引力では 3 点 の実測值を細線でつないであるが，これは 3 点の実測値 の平均值を示したものであり，いずれの場合でも吸引力 の分布は等分布となっている. なお， $D=5 \mathrm{~cm}$ の場合 の $p_{3}$ の実測值は, 水圧計が故障して計測できなかった ために, $p_{t}$ の平均值は $p_{1}$ と $p_{2}$ の 2 点の実測值より 求めた. これは, 他の $D=5 \mathrm{~cm}$ の実験においても， $p_{1}$, $p_{2}, p_{3}$ はほとんど同程度の值となり等分布になることが 確認されているので， $p_{1}$ と $p_{2}$ の平均值を $p_{t}$ として 用いても大差はない，周面水圧においては，それぞれ実 測值を実線でつないであるが，模型の最下端の水圧の值 は吸引力の平均值 $p_{t}$ の值である. このように, 周面水 圧は三角形分布よりもいくぶん型の分布形状となり， 根入り深さが浅くなるにしたがって，吸引力は $p_{t}$ を底
辺とする三角形分布に近づいている. しかし，この場合 も2. で述べたように，あくまでも吸引力が等分布に発 生する根入り深さ，すなわち， $D / 2 B$ が約 0.3 より大き い範囲での考察である. Fig. 5 の下図は $p_{t}, p_{4 t}, p_{5 t}$, $p_{6 t}$ の実測值を引き上げ速度 $V$ に応じて示したもので あり，周面水圧も吸引力と同じ傾向で $V$ が大きくなる にしたがって増加していることがわかる。

\section{（2）吸引力が周面摩擦力におよぼす影響}

前項で述べたように吸引力が発生すると周面の水圧も 減少する. この周面水圧の 減少が 周面摩擦力に 影響す る. Fig. 6 は引き上げ力の極大值 $T_{p}$, 吸引力の合力 $P_{t}$ および周面摩擦力 $F_{t}$ の実測值を引き上げ速度 $V$ に 応じて示した一例である.ここでも, 周面摩擦力は実験 で直接計測できないので, Fig. 3 の場合と同様に, $F_{t}$ $=T_{p}-P_{t}-\left(W-U_{t}\right)$ で計算した值をプロットしてあ る.この図でわかるように, $F_{t}$ \& $T_{p}, P_{t}$ と同様に $V$ に応じて増加している.すなわち， $F_{t}$ の值は Fig. 7 や Fig. 8 に示寸ように, 吸引力 $p_{t}$ に比例して増加して いることがわかる.このような現象は杭などの周面摩擦 力の算定において一般に使用される静力学的な算定式だ
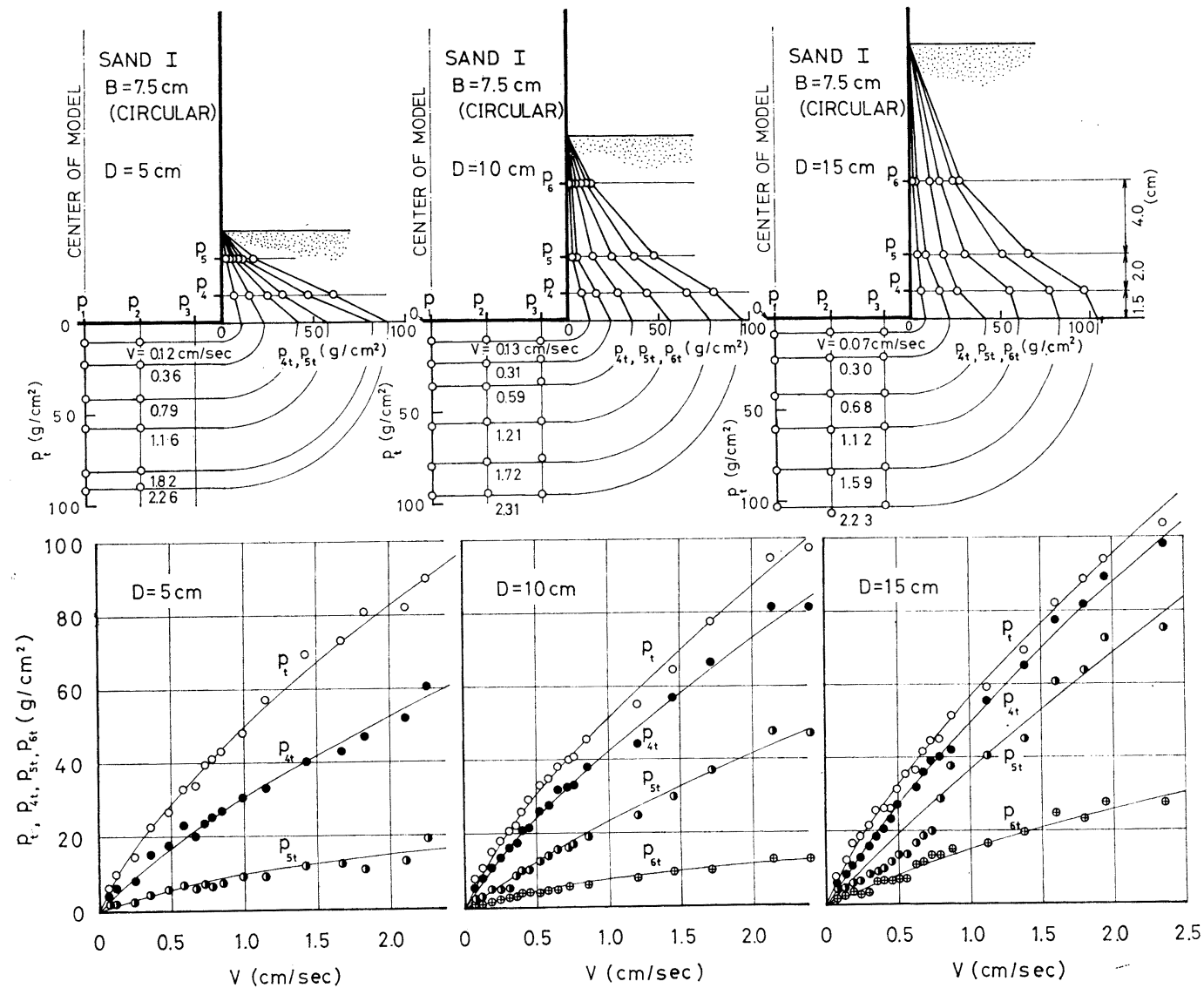

Fig. 5 Distribution of Suction Pressure and Decreased Side Water Pressure 
けでは解決できない，周面摩擦力の増加の原因としてま ず考えられることは，底面に発生する吸引力によって生 じる周面付近の応力状態の変化である.

いま，筒状体の周面の深さ $z$ の点に作用する全応力を

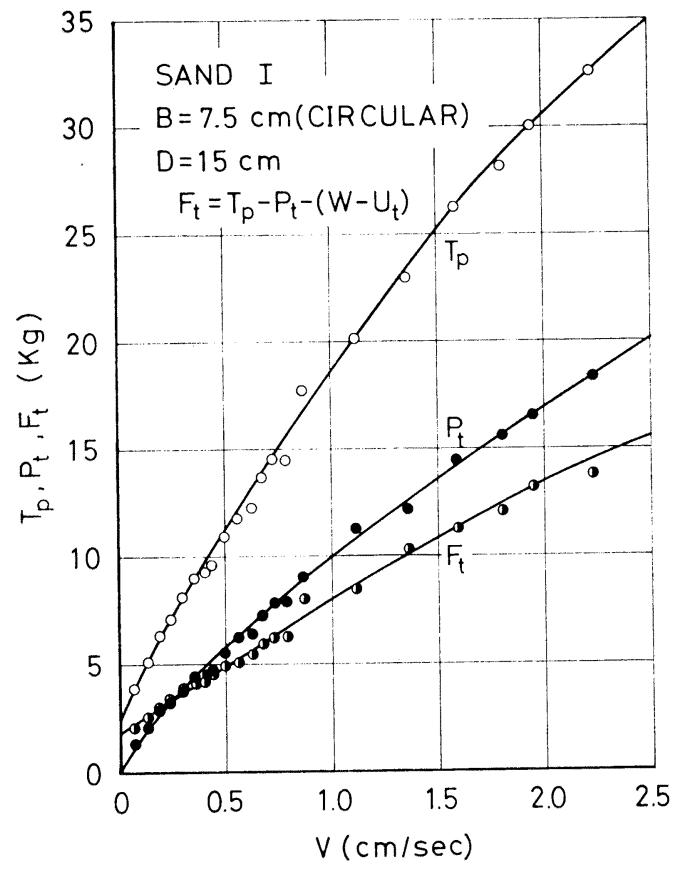

Fig. 6 Measured Values of $T_{p}, P_{t}$ and $F_{t}$

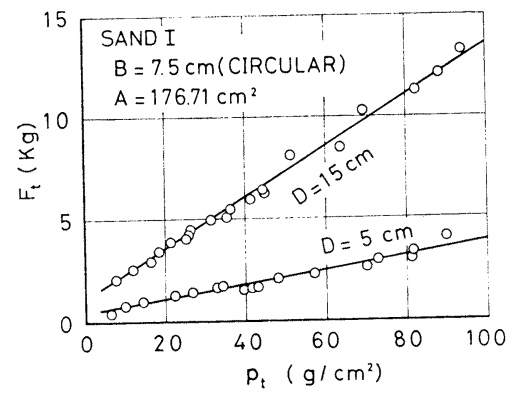

Fig. 7 Relationship between Frictional Force and Suction Pressure (SAND I, CIRCULAR(2))

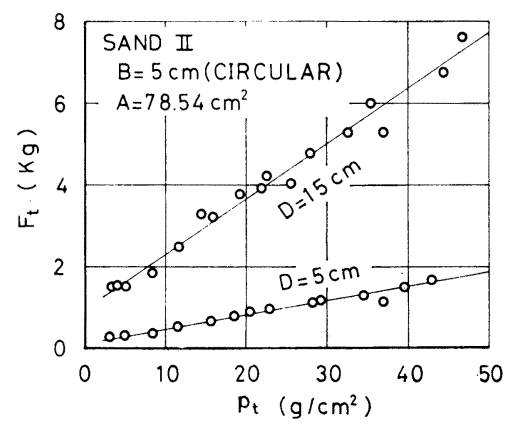

Fig. 8 Relationship between Frictional Force and Suction Pressure(SAND II, CIRCULAR(1)) $\sigma$, 有効応力を $\sigma^{\prime}$, 中立応力を $u$ とするならば, $\sigma$ は次 の式となる.

$$
\sigma=\sigma^{\prime}+u
$$

筒状体を引き上げ，底面に吸引力が発生すると，周面 に作用する中立応力 $u$ は静止のときよりも減少する. この減少量を $\Delta u$ とすると, 全応力 $\sigma$ は一定であると 考えることができるから, 有効忘力 $\sigma^{\prime}$ は $\Delta u$ だけ増加 することになる ${ }^{13)}$.この $\Delta u$ が実験で計測した周面水圧 の減少量にほかならない.

一方, 砂地盤における杭などの周面摩擦力を静力学的 に求める場合, 周面の深さ $z$ における有効応力は, 一般 にその位置の有効鉛直応力 $\sigma_{v}{ }^{\prime}$ に横力係数 $K_{L}$ を乗じ て計算する方法がとられている ${ }^{14)}$.

$$
\sigma^{\prime}=K_{L} \sigma_{v}{ }^{\prime}=K_{L} r^{\prime} z
$$

ここで, $r^{\prime}$ は砂の水中単位体積重量である.

以上述べたところにより, 吸引力の発生をともなら場 合の周面に作用する有効応力は, 静力学的に求められる 有効応力と周面の中立応力の減少により増加した有効応 力の和として次のように書ける.

$$
\sigma^{\prime}=K_{L} r^{\prime} z+\Delta u \text {. }
$$

式 (4)より, 周面摩擦力 $F_{t}$ は,

$$
F_{t}=\mu L \int_{0}^{D}\left(K_{L} r^{\prime} z+\Delta u_{t}\right) d z
$$

のように表わすことができる．この式で， $\mu$ は筒状体の 周面と砂との間の摩擦係数, $L$ は筒状体の周長, $D$ は 根入り梁さである. $\Delta u_{t}$ は (1) で述べたように地切り力 の極大值に対応する周面の中立応力（水圧）の減少量, すなわち, 有効応力の増加量である.

横力係数 $K_{L}$ については杭の支持力や引き抜き抵抗 力の計算において種々の值が提出されている(12),14). 本 実験においては, 引き上げ速度 $V$ が非常におそく, 発 生する吸引力が小さいために, 吸引力が周面摩擦力に影 響しない場合の実測值から逆算すると $K_{L}=1.0$ であっ た. 摩擦係数 $\mu$ は, 筒状模型と同一材料で作った $10 \times$ $30 \mathrm{~cm}$ の板を用いて, すべり出し抵抗試験より求めた. その結果, SAND I で 0.4, SAND II で 0.37 であっ た. また, 砂の水中単位体積重量 $r^{\prime}$ は SAND I で 1.0 , SAND II で 0.98 である.

Fig. 9 は周面摩擦力の実測值と式 (5) による計算值 を比較して示したものである. 丸印は Fig. 6 と同様に $F_{t}=T_{p}-P_{t}-\left(W-U_{t}\right)$ から求めた実測值である. 実 線は, 周面の中立応力 (水圧) の減少量 $\Delta u_{t}$ を Fig. 5 に示した周面水圧の実測值の分布形状にしたがって忠実 に積分し, 式 (5) を用いて計算した值である. 計算值 は, 周面水圧の分布形状に実測值をそのまま用いたため にスムースカーブとはならないが，実測值と非常によく 一致している.このことは，これまで述べた周面摩擦力 


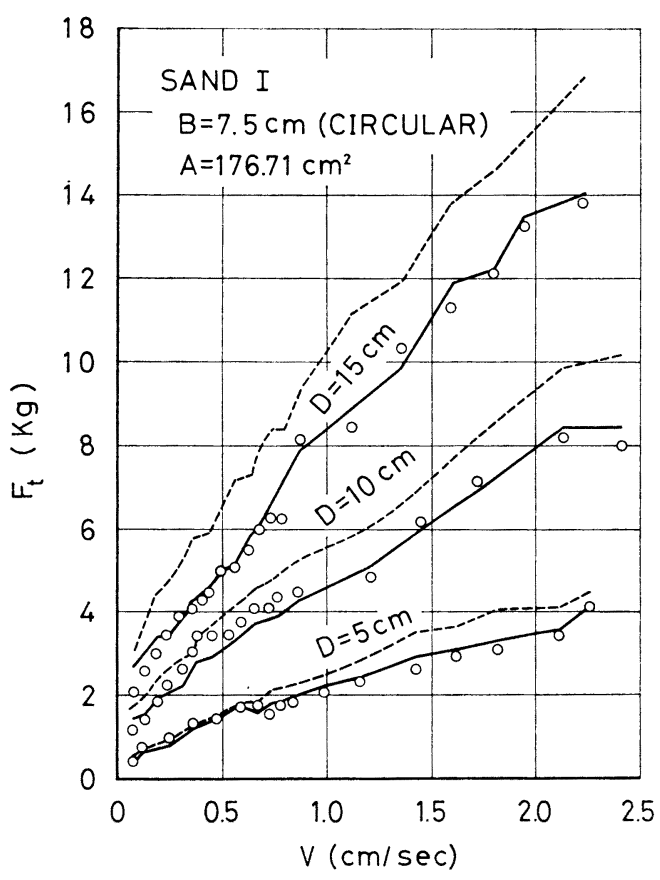

Fig. 9 Comparison between Values of $F_{t}$ Calculated According to Distribution of Decreased Side Water Pressure Shown in Fig. 5 and Measured Values

に対する考え方の正しいことを示すと同時に式 (5) の妥 当性を示している. 破線は周面水圧の分布形状を, 吸引 力 $p_{t}$ の実測值を底辺とし砂表面を頂点とする三角形分 布として, 式 (5) で $F_{t}$ を計算した值である. 当然のこ とではあるが, 破線の值は実線の值よりも大きくなる.
形状を把握しなければならない.

\section{（3）周面摩擦力の計算式}

筒状体の周面摩擦力を式 (5) で計算するためには, 吸 引力の発生により減少した周面水圧 $\Delta u_{t}$ の分布形状を 決定しなければならない。この分布形状は Fig. 5 に示 したように，三角形分布よりもいくぶん回型の分布形状 であるが，いま，解析を容易にするために，近似的に Fig. 10 に示すように吸引力 $p_{t}$ を底辺とし砂表面を頂 点とする三角形分布と仮定する. 分布形状をこのように 仮定することは，有効応力 $\sigma^{\prime}$ を実際よりも大きめに見 積ることであり, 式 (5) で, 周面摩擦力を算定する場 合，実際よりも安全側で計算することになる．Fig. 10 の分布形状で, 深さ $z$ における $\Delta u_{t}$ は吸引力 $p_{t}$ の関 数として,

$$
\Delta u_{t}=\frac{z}{D} p_{t}
$$

で表わされ，周面摩擦力 $F_{t}$ は上式を式 (5) に代入して 積分すると次式となる.

$$
F_{t}=\frac{1}{2} \mu K_{L} r^{\prime} L D^{2}+\frac{1}{2} \mu L D p_{t}
$$

上式の右辺第 1 項は杭などの周面摩擦力の計算に用い られる静力学的な式であり, 第 2 項は筒状体の底面に吸 引力が発生し, 周面の水圧が減少することによっておこ る周面摩擦力の増加量を表わす式である. この第 1 項を $F_{1}$, 第 2 項を $F_{2}$ とすると $F_{t}=F_{1}+F_{2}$ となる.

Fig. 11 は周面摩擦力 $F_{t}$ について, 実測值 (丸印) と 計算值（実線および破線）を比較して示した例であ る. 計算值は式 (6) を用いて計算したが, 式 (6) の吸引

以上述べてきたように， 吸引力の発生をともなう 場合の筒状体の周面摩擦 力には, 周面の水圧の減 少が大きく影響するが， 式 (5) で十分正確に周面 摩擦力を計算できる.し かし，そのためには周面 水圧の減少量 $\Delta u_{t}$ の分布

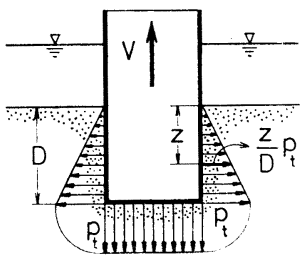

Fig. 10

Triangular Distribution of Decreased Water Pressure on Side of Cylinder
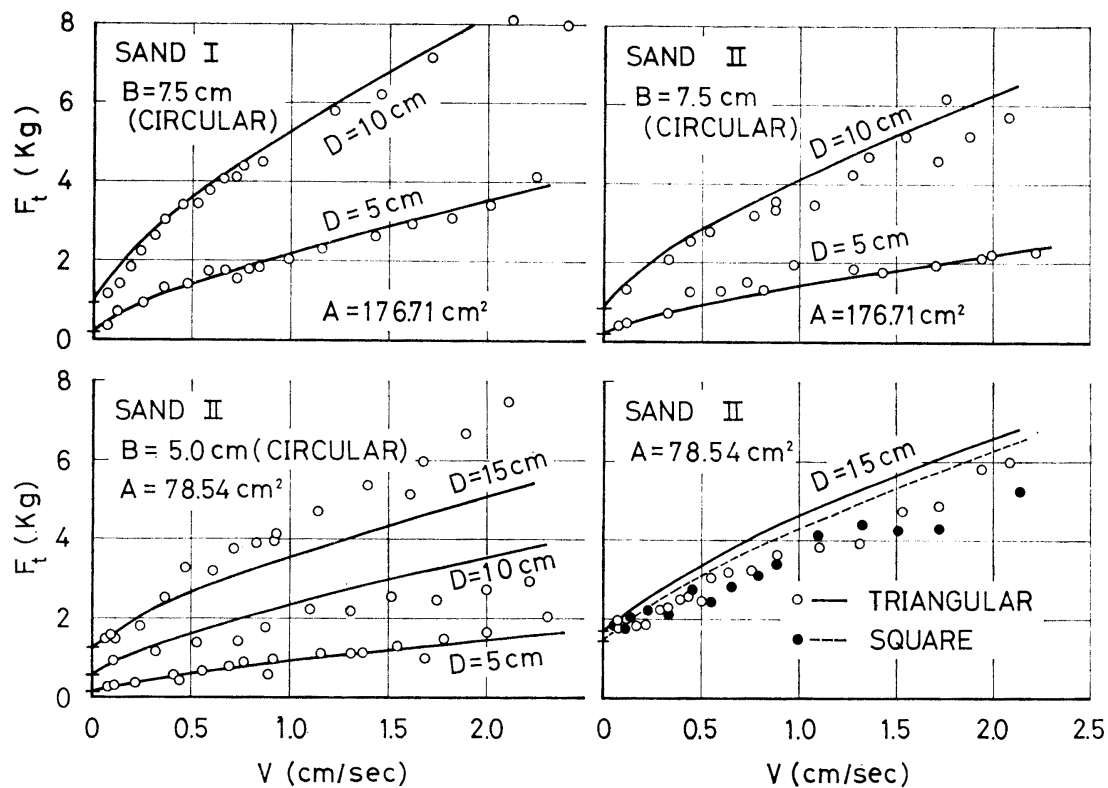

Fig. 11 Comparison between Measured and Calculated Values of Frictional Force $F_{t}$ 
力 $p_{t}$ の值は式 (3) から計算した. $\mu, K_{L}, r^{\prime}$ の值には （2）で述べた值を用いた. $V=0$ の付近では吸引力 $p_{t}$ の值は非常に小さく，したがって， $F_{2}=0$ であるから $F_{t}=F_{1}$ となる. この図の $V=0$ の縦軸上に一印で示 した值は $F_{1}$ の計算值であり，V=0 の近くにある実測 値から判断して $K_{L}=1.0$ の值は, この実験に関しては,

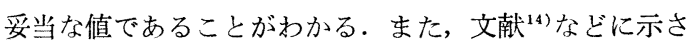
れている $K_{L}$ の值からみても一応妥当な值であるとは 考えられるが，しかし，この值は模型実験より求めた值 であり，また，杭などの支持力や引き抜き抵抗力に関し てもまだ確定した值が出されてないことも考慮に入れる と，今後 $K_{L}$ の值について治検討する必要があると考 えられる。

Fig. 11 でわかるように， $V$ が大きく，吸引力が大 きい場合には， $F_{1}$ の值に比較して $F_{2}$ の值が大きくな る.このことは, 海底に着地している物体のように根入 り媣さが小さく, 吸引力の発生を伴う場合の周面摩擦力 に対しては $F_{2}$ の算定が重要であることを示している.

一方, 根入り梁さ $D$ の増加に応じる吸引力 $p_{t}$ の増 加は, 前報10)でも述べたようにさほど大きくないために

(Fig. 5 参照)， $p_{t}$ の関数である $F_{2}$ の増加もさほど大 きくない。しかし， $F_{1}$ は $D$ の 2 乗で増 加するために，根入り梁さが大きくなる 上， $F_{1}$ が $F_{2}$ よりも大きな值となる場 合もあるので注意しなければならない，

また，Fig. 11 で，特殊な例をのぞけ ば，一般に計算值が実測值よりもいくぶ ん大きくなっている.これは周面水圧の 分布形状を三角形分布と仮定し, 実際上 りも水圧を大きめに見積もって計算した ためと考えられる。

これらの図から判断して, 砂地盤の海 底から筒状体を引き上げる場合の周面摩 擦力は式 (6) を用いて計算できることが わかる。

\section{4. 筒状体の地切りカ}

海底から筒状体を引き上げる場合の最 大地切り力 $T_{p}$ は吸引力の合力 $P_{t}$, 周 面摩擦力 $F_{t}$ および重量と浮力の差 $W$ $U_{t}$ の和として計算することができる. $P_{t}$ は式 (3) で計算される $p_{t}$ と筒状体 の底面積 $A$ との積であり, $F_{t}$ は式 (6) を用いて計算できる. 浮力 $U_{t}$ は地切り 力が極大值に達したときの筒状体の変位 を $d_{t}$ とするならば， $U_{t}=r_{w} A(H+D-$ $d_{t}$ ) の式で表わすことができる ( $H$ は水深).しかし，

3. で述べたように地切り力の極大值は引き上げ変位 $d_{t}$ が比較的小さい範囲で発生し (Fig. 3 参照), $H+D$ に 比較して $d_{t}$ 沙非常に小さい，そのために，筒状体が静 止しているときの浮力 $U_{0}=r_{w} A(H+D)$ の值を用いて もさしつかえない，

式 (3), (6) をもとに地切り力の算定式をまとめて書く と次のようになる.

$$
\begin{aligned}
T_{p}=P_{t} & +F_{t}+\left(W-U_{0}\right) \\
P_{t} & =A p_{t} \\
F_{t} & =\frac{1}{2} \mu K_{L} r^{\prime} L D^{2}+\frac{1}{2} \mu L D p_{t} \\
U_{0} & =\gamma_{w} A(H+D) \\
p_{t} & =1.188\left(\frac{\Phi_{r_{w}} A V}{\alpha k L}\right)^{0.726}
\end{aligned}
$$

Fig. 12 は地切りカ $T_{p}$ について, 式 (7) で計算し た值 (実線) と実測值（丸印）を比較して示した一例で ある. 図に透水係数 $k$ の值も併記したが，これは同一の 砂を用いた実験でも水温が異なる場合もあり， $k$ の值が 違うためである (SAND II,$D=10 \mathrm{~cm}$ ). この図でわか るように，実測值と計算值はよく一致していて，式 (7) の妥当性を示している. しかし, これらは模型実験の結

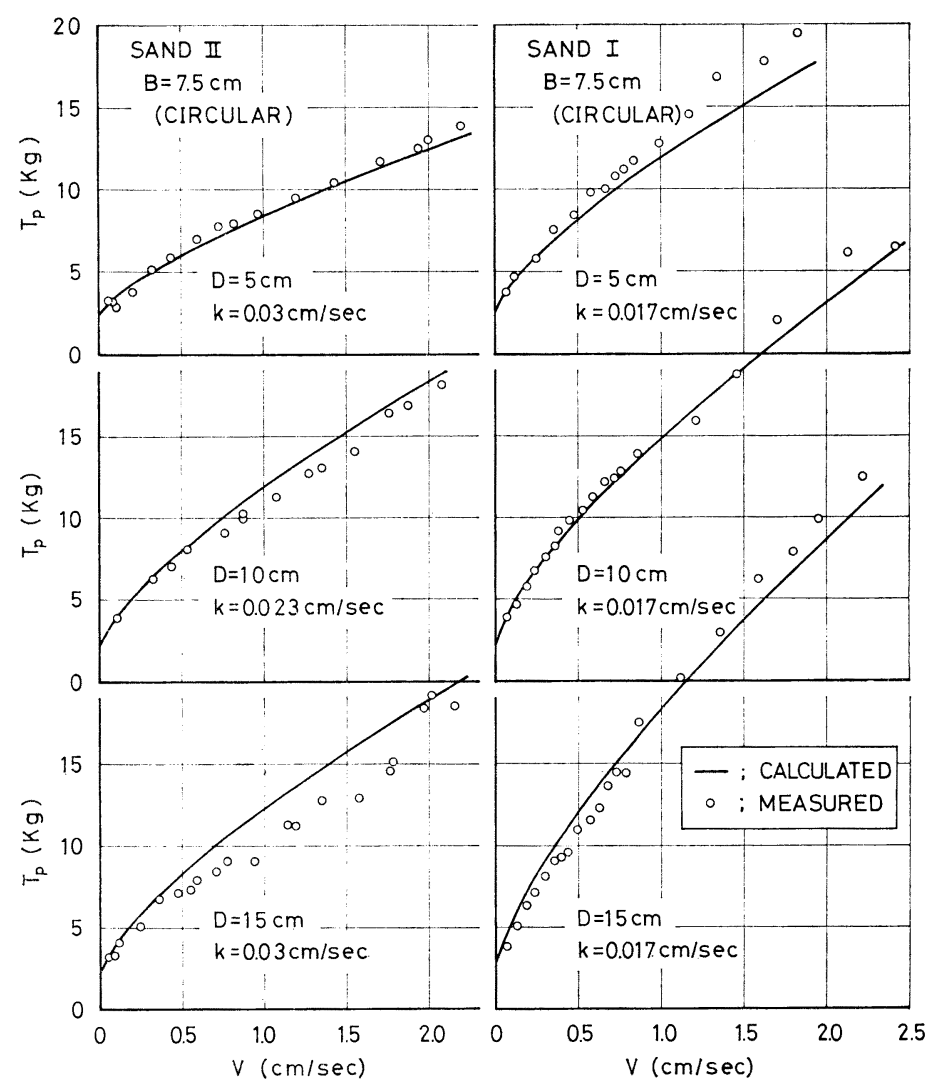

Fig. 12 Comparison between Measured and Calculated Values of Breakout Force $T_{p}$ 
果であり，より研究を確実なものにするためには，実物 大の筒状体による確認実験を行ってみる必要もあると考 えられる。

\section{5.むすび}

以上述べてきたように, 砂地盤の海底から筒状体を引 き上げる場合, その底面に作用する吸引力と周面に作用 する摩擦力を, 模型実験をもとにそれぞれ考察すること により，筒状体の地切り力を算定するための計算式を誘 導することができた.これまでに述べてきたことを結論 としてまとめると次のことがいえる.

（1）底面に吸引力が発生すると周面の水圧も減少す る. この減少した水圧 $\Delta u_{t}$ の周面における分布は, 吸引 力が等分布に発生する根入り媣さ, 寸なわち, $D / 2 B>$ 0.3 の範囲では, Fig. 5 に示したように, 三角形分布 よりもいくぶん凹型の分布形状となり, 根入り深さが浅 いほど三角形分布に近い.

（2）地切り力の極大值に対応する周面摩擦力 $F_{t}$ は 静力学的な摩擦力 $F_{1}$ と吸引力の発生によっておこる周 面摩擦力の増加量 $F_{2}$ との和であり, 近似的に式 (6) で 算定することができる.

a) $F_{1}$ は杭などの 周面摩擦力の 算定に用いられる計 算法を使用し, 式 (6) の第 1 項で表わすことができる.

b) $F_{2}$ は吸引力の発生により周面の水圧が減少し, 有効応力が増加することによっておこる周面摩擦力の増 加量であり, 吸引力 $p_{t}$ に比例して増加する. 周面水圧 $\Delta u_{t}$ の分布形状を近似的に， $p_{t}$ を底辺とし砂表面を頂 点とする三角形分布と仮定すると, $F_{2}$ は式 (6) の第 2 項で表わすことができる.

（3）地切り力の極大值 $T_{p}$ は引き上げ変位が小さい 範囲で発生するために, 筒状体の 浮力の変化量は小さ い. そのために, 地切り力の極大值に対応する浮力 $U_{t}$ のかわりに，筒状体が静止しているときの浮力 $U_{0}$ を用 いてもさしつかえない.

（4）地切り力の極大值 $T_{p}$ は吸引力の合力 $P_{t}$, 周 面摩擦力 $F_{t}$ および筒状体の重量と浮力の差 $W-U_{0}$ の 和として表わすことができ, 式 (7) を用いて計算でき る.

ここで行った実験は筒状模型を用いた基礎実験であ
り, 今後, より研究を確実なものにするためには, 実物 大の模型による実験や現地実験などにより確認をする必 要むあると考えられる.

また，吸引力の発生現象や地切り力の大きさなども異 なると考えられる粘性地盤についても現在実験を進めて いる.

最後にこの研究に貴重なご助言をいただいた名古屋 大学市原教授に感謝いたします.

\section{参 考 文献}

1) Ninomiya, K., Tagaya, K. and Murase, Y. : A Study on Suction Breaker and Scouring of a Submersible Offshore Structure, OTC, pp. II 297 II 304, 1972.

2) Lee, H.J. : Breakout of Partially Embedded Objects from Cohesive Seafloor Soils, OTC, pp. II $789 \sim$ II 802, 1974.

3) Roderick, G.L. and Ayoub Lubbad : Effect of Objects Insitu Time on Bottom Breakout, OTC, pp. 355 362, 1975.

4) Muga, B.J. : Bottom Breakout Forces, Civil Engineering in the Oceans, ASCE Conference, San Francisco, pp. 569 600, 1967.

5) Liu, C.L. : Ocean Sediment Holding Strength against Breakout of Partially Embedded Objects, Civil Engineering in the Oceans II, ASCE Conference, Miami Beach, pp. 105 116, 1969.

6) Vesic, A.S. : Breakout Resistance of Objects Embedded in Ocean Bottom, Civil Engineering in the Oceans II, ASCE Conference, Miami Beach, pp. 137 $165,1969$.

7) Colp, J.L. and Herbich, J.B. : Inclined Pullout Forces for Embedded Plate Anchors, OTC, pp. 333 342, 1975.

8) Bemben, S.M. and Kalajian, E.H. : The Vertical Holding Capacity of Marine Anchors in Sand, Civil Engineering in the Oceans II, ASCE Conference Miami Beach, pp. 117 136, 1969.

9) 運輸省船舶局: 浮遊式大型海洋模泚物研究荓発報告書, pp. 100 101, 1975.

10）井上令作・岩井勝美：砂地盤の海底加筒状基礎を引き 拔く際に生じる吸引力, 土木学会論文報告集, 第 253 号, pp. 85 93, 1976.

11) Harr, M.E. : Groundwater and Seepage, McGrawHill Book Company, pp. 136 137, 1962.

12) Ireland, H.O. : Pulling Tests on Piles in Sand, Proc. 4th. SMFE, pp. 43 45, 1957.

13）土質工学会綝：土質工学ハンドブック，技報堂， p. 82 , 1965.

14）同上, pp. $424 \sim 425$.

(1976.8.20 - 受付) 